\title{
Leadership on the Commons: Wealth Distribution, Co-provision and Service Delivery
}

\author{
MATHEW KURIAN* \& TON DIETZ** \\ *Development Planning Unit, University College London, UK; **African Studies Centre, Leiden, The Netherlands
}

Final version received March 2013

\begin{abstract}
There has been a long running debate among public choice theorists on the effects of heterogeneity on collective action. Our longitudinal study leads us to conclude that collective action outcomes are shaped not simply by the attributes of heterogeneity themselves but by the processes by which those attributes interact overtime with the bio-physical and institutional environment. From a methodological point of view how one integrates conceptualization of forms of heterogeneity with recognition of their axis of influence; themselves dependent upon attributes of field-level situations is crucial for analysis of collective action. These findings have public policy implications for targeting of poor and non-poor resource users and management of environmental feedback loops.
\end{abstract}

\section{Introduction}

Approximately 1.2 billion poor and 800 million malnourished people in the world rely on agriculture for food and income security (Rijsberman, 2004). Common pool goods like forests, grazing pasture or irrigation systems while non-excludable and 'rivalrous' in consumption, sustain multiple facets of livelihoods ranging from farming to cooking, livestock rearing and house construction (Beck \& Nesmith, 2001; McKean, 2000). Community forestry literature suggests that reliance of marginal or landless households on common pool resources tends to increase with adverse terms of trade or declining farm productivity (Byron \& Arnold, 1999). Studies have also valued the economic costs associated with a reduction in access to water as a result of deforestation induced soil erosion to emphasise the importance of conserving such resources (Myers, 1997).

Parastatal agencies such as irrigation and forest departments in developing countries have historically played an important role in creating physical assets (such as dams and trees) and arranging for their maintenance (Brookfield \& Blaikie, 1987). However, over the years there has been a realisation that the public sector has failed to ensure cost-effective management due to rent seeking behaviour by public officials and resulting conflicts with local communities (Peluso, 1992). Such trends have impaired mechanisms to monitor access to common pool resources such as forests and exacerbated problems of soil erosion. In recent years public choice theory has successfully argued that communitybased organisations can provide low-cost arenas for management of Common Pool Resources (CPRs) (North, 1995; Ostrom, 1990). Scholars have pointed out that factors such as trust, density of social ties,

Correspondence Address: M. Kurian, Development Planning Unit, University College London, 34 Tavistock Road, London, UK. Email: m.kurian@ucl.ac.uk

An Online Appendix is available for this article which can be accessed via the online version of this journal available at http://dx. doi.org/10.1080/00220388.2013.822068

(C) 2013 The Author(s). Published by Taylor \& Francis.

This is an Open Access article distributed under the terms of the Creative Commons Attribution License http://creativecommons. org/licenses/by/3.0/, which permits unrestricted use, distribution, and reproduction in any medium, provided the original work is properly cited. The moral rights of the named author(s) have been asserted. 
shared norms and minimal recognition by governments of the rights of citizens to organise may significantly lower transaction costs of monitoring access to CPRs (Woolcock \& Narayan, 2001).

Given historical trends pointing to the role of predatory states in crafting revenue settlements that resulted in eviction of tenants with customary rights, co-management projects involving partnerships between governments and community-based organisations have been viewed with scepticism (Shanmugarathnam, 1996). This scepticism is based on a couple of likely scenarios: 1) benefits of co-management will be captured by elites (Dasgupta \& Beard, 2007), and 2) groups characterised by unequal asset distribution are most likely to produce an unequal distribution of benefits from management of CPRs (Platteau \& Gaspart, 2003). Carrying on in this vein, a number of studies conclude that homogeneity of economic interests is essential for cooperation (Ruttan, 2008). A study in Taiwan revealed a negative relationship between inequality in endowments (land holdings) and performance of irrigation organisations (Lam, 2001). Another study of 10 irrigation reservoirs in India suggested that the smaller the variance in farm size, the more farmers were likely to form water user associations (Easter \& Palanisami, 1986). Similarly, a study in Nepal revealed a negative relationship between variance in average family income among irrigators and cooperation to operate and maintain the system (Tang, 1992).

In 2000, we undertook an assessment of a Ford Foundation project that aimed to reverse soil erosion in the Indian Himalayas. The assessment included a survey of 28 community-based watershed management groups known as Hill Resource Management Societies (HRMS) responsible for management of 45 earthen dams. Our survey revealed the complicity of the Haryana Forest Department (HFD) in the faulty infrastructure design, which resulted in only 17 per cent of the dams functioning to their lifetime capacity of 20 years (Kurian \& Dietz, 2007). From a collective action perspective we found that of the eight HRMS with functioning dams those groups that exhibited successful cooperation were the ones characterised by heterogeneity in asset distribution and a higher interest in CPRs on account of: (a) lower aggregate engagement in non-farm labour markets and (b) limited access to private tubewells. To explore the relationship between group composition and collective action, we undertook a comparative case study. Our methodology is innovative because: 1) The composite index of interest and endowments based on assessments of household food security constitutes an improvement over single metric measures (land or income) of wealth distribution while allowing for comparisons over time, and 2) forest vegetation analysis makes it possible to link dam management to condition of natural resources.

Our comparative case study revealed that individual entrepreneurs made it possible for collective institutional arrangements to flourish in heterogeneous groups even after the conclusion of the Ford Foundation project. Entrepreneurs were actively engaged in crafting rules for benefit distribution, negotiating with village elites, liaising with local governments, making up-front investments for operation and maintenance of infrastructure, resolving conflicts and managing climate-based risks (Jones, 2004; Vedeld, 2000). By playing this coordination role entrepreneurs were providing a service to both governments and local resource users; we call the undertaking of this role 'co-provision'.

We returned in 2008 to re-study a site of successful entrepreneur-led collective action. This article reports on the findings of our revisit study to argue that effective co-provision is made possible by leaders who operate in a milieu of caste and gender-based hierarchical social relations, exercise of discretion by public officials, uncertainty in factor and product markets and risks posed by variability in climatic, soil and groundwater conditions (Long \& Ploeg, 1992). Our analysis extends existing theories by demonstrating: (a) a rational action framework can lead to an over-statement of risks of elite capture of project benefits due to inadequate historical analysis of community power relations, and (b) heterogeneity can provide a basis for construction of social hierarchy; but its actual influence on collective action is mediated by trust and social norms that arise from a history of past cooperation involving the poor and non-poor (Johnson, 2004). Subsequent sections of the article examines the evolution of the Ford Foundation watershed management project by employing a political ecology framework followed by a description of data and methods employed by the analysis. Key findings of our revisit study are discussed from the perspective of their implications for theory and development practice. 


\section{Political Ecology of Watershed Management in the Haryana Shiwaliks}

\section{Soil Erosion, Public Revenues and Participatory Natural Resources Management}

The Shiwalik hill forests comprising approximately 6.5 per cent of the land area of the North Indian state of Haryana perform an important ecological function of mitigating the effects of soil erosion. In the early 1970s, the Forest Department argued that open cattle grazing and fuel wood collection by local communities had endangered the soil erosion function of the Shiwalik forests. The most visible manifestation of forest degradation was the increasing rate of siltation of the Sukhna reservoir in the state capital, Chandigarh (Arya \& Samra, 1995). The reservoir was an important source of tourism revenue and preliminary analyses indicated that the source of the risk lay in rapid deforestation of the catchment areas located in proximity to the village of Sukhomajiri (Dhar, 1994, p. 20).

The Ford Foundation facilitated a community-based forest management initiative that involved construction of water harvesting dams to arrest movement of silt. However, when villagers destroyed check dams that were constructed and continued to open-graze cattle in the forests, a substantive dialogue was initiated that resulted in usufruct sharing agreements between the forest department and local communities (Hill Resource Management Societies (HRMS). The usufruct sharing agreements that initially covered fuel wood, fodder and fibre grasses was later extended to include water from dams constructed by the Haryana Forest Department (HFD) with in-kind contribution of labour by the HRMS. The dams, by providing supplemental irrigation for the winter wheat crop, proved a powerful incentive in encouraging forest dependent communities to change their behaviour from open grazing to stall feeding of livestock (Grewal, Samra, Mittal, \& Agnihotri, 1995). The Sukhomajiri model became a success story because irrigation from earthen dams yielded multiple benefits: increased fodder production on private fields and increased production of cattle dung used as cooking fuel in the area. Increased production of fodder grass and cattle dung led to a dramatic reduction in open cattle grazing and harvesting of fuel wood from forests, which was in turn to lead to forest regeneration and lower levels of soil erosion.

Besides reversing levels of soil erosion, the Sukhomajiri watershed management model ushered in a fresh perspective on the role of community participation in managing publicly owned forests (Ostrom, 1996). A Working Plan document of the Haryana forest department made its commitment to comanagement explicit by stating:

For the State government, there will be no loss in existing revenues. The present levels of revenue will be maintained and in certain cases, this will increase over time. Simultaneously, through the government's adoption of the policy of sharing the bulk of the increased production resulted from villager's participation. The latter's economic status will improve substantially without any additional cost. Further, with villager's accepting responsibility for protection and management of forest areas near villages, the Department's future costs for their protection and rehabilitation will be substantially reduced. (Kurian \& Dietz, 2007)

\section{Collusion in Infrastructure Construction}

The success of the Sukhomajiri project provided the HFD with the legitimacy it needed to go on a dam construction spree. Between 1985 and 1998, 45 water-harvesting dams were constructed in the Pinjore forest division. Lower level functionaries of the HFD exercised considerable discretion over decisions regarding design, operation and maintenance of the earthen dams. In many cases, faulty design was overlooked to justify expensive repairs to parts of the dam that was washed away in the rains. The institutional framework encouraged collusion because villagers desired a share of the spoils of public investment, which took the form of provision of wage labour for dam construction and contract awards for specific tasks such as transport of distribution pipes from government warehouses to dam sites. However, in response to rising costs of infrastructure construction and evidence of rent-seeking behaviour by field staff, the HFD resorted to public auctions whereby the highest bidder would be granted contracts for specific tasks. 


\section{Role for Private Initiative}

The notion that public auctions could facilitate greater transparency gradually led the HFD to introduce auctions for sale of forest produce and rights to distribute water from earthen dams. Over time, a pattern evolved whereby contractors from outside the village bid higher than the HRMS at public auctions. Although no restrictions were placed on participation of outsiders, villagers preferred that contractors from within their village purchase rights to forest products and water distribution. This preference is linked to their perception that a contractor drawn from within the village would be sensitive to individual household requirements for forest products and would likely accept instalment payments for services rendered. Further, local contractors were more likely to invest a share of the proceeds from sale of forest and water products in maintenance of the dam itself and indulge in gift giving in the form of donations to repair local schools and temples (Datta \& Varalakshmi, 1999, p. 117).

\section{Broader Political Economy Trends}

Community based forest management in the Shiwalik hills is not insulated from wider political economic trends occurring in Haryana in particular and India in general. Three trends are important. First, there has been a marked integration of farming populations in markets for non-farm labour and dairy products on account of a secular decline in returns from pursuing a purely agricultural-based livelihood strategy (Bhalla, 1999; Varalakshmi, 1993). Others have pointed out that given cultural norms in the region that prevent women from engaging in non-farm labour, women's workload in the domestic economy would have most likely risen to compensate for time spent away from the settlement by male members of households on account of their engagement in non-farm employment (Agrawal, 1997). Second, in keeping with a larger trend of removal of import controls following the liberalisation of the Indian economy, imported paper and pulp have depressed demand for fibre grass sourced from the Shiwalik hill forests (Kurian, 1998). Finally, fiscal mechanisms have become regressive in response to growing profits of community-based forest management cooperatives (Kurian \& Dietz, 2007).

\section{Hierarchy, Ecology and Leadership: Reflections on Data and Method}

Our comparative case study involved two HRMS: Bharauli and Thadion. Bharauli exhibited success with collective action and involved entrepreneur-based service provision while Thadion failed with collective action and was under management of the HRMS. We found Bharauli to be relatively more heterogeneous when compared to Thadion, but despite being a relatively heterogeneous village in terms of wealth/endowment distribution, Bharauli was more effective in delivering irrigation services from the earthen dam. Between 1998 and 2000, an entrepreneur from within the water user group had purchased water distribution rights. By contrast in Thadion during the same period, the HRMS was responsible for providing water services and failed to ensure compliance with water user fees. Three factors can explain the differences in collective action outcomes in Bharauli and Thadion (Kurian \& Dietz, 2007).

(1) Land ownership, hierarchical social relations and labour market structure. Bharauli is a multicaste village with 80 households while Thadion with 50 households is a relatively homogeneous village in terms of caste composition. Bharauli reflects delicate power relations because it is a multi-caste village with a skewed pattern of land ownership. Hierarchical social relations are reflected in occupational specialisation and segregation. Occupational specialisation defined by caste was also evident from the fact that the tarkhans provided blacksmith services for other caste groups and the rajput caste group monopolised the local transport business. Caste-based notions of impurity and hierarchy prevent the landless or untouchable castes from using communal drinking water sources, ponds or temples frequented by other castes. Caste also influences residential location of different groups within the village while untouchables invited to marriage 
Table 1. Variance for variables of household endowment scores

\begin{tabular}{lcc}
\hline Variable & Bharauli HRMS & Thadion HRMS \\
\hline Average irrigated land (ha) & 83.3 & 64.1 \\
Average size of land owned (ha) & 51 & 55.1 \\
Average livestock size (number) & 82.6 & 86.1 \\
Average family size (number) & 40 & 45.7 \\
\hline
\end{tabular}

Source: Kurian \& Dietz, 2007.

ceremonies in the village are expected to sit at a distance from others and use separate utensils. By contrast such caste-based patterns of hierarchy, social segregation or occupational specialisation were absent in the neighbouring village of Thadion. In Bharauli, the structure of the labour market reinforces hierarchical social relations. For instance, landless households who work as hired labour on other people's fields or as domestic hands in the homes of the wealthy are not always paid in wages but in kind, such as food or insurance during times of natural disasters like floods. From a gender perspective, cultural norms that prevent participation of girls in the nonfarm labour market can make families with limited supply of male children highly reliant on farm production.

(2) Differences in local ecology and location of farm plots. We found that Bharauli HRMS differed from Thadion HRMS with respect to local ecology (Wade, 1988). Groundwater is relatively easy to find in Thadion while in Bharauli, the groundwater table is deep. The prohibitive groundwater drilling costs increased farmers' reliance on common pool resources in Bharauli where farmers also had access to $k u h l s^{1}$ for land irrigated by the dam. However, the kuhls run dry by early February and, if rains do not arrive by early March, the supply of the last round of supplemental irrigation for wheat depends on water from the earthen dam. If rains fail altogether, reliance on water from the dam becomes even more critical. Not surprisingly, we found that average land irrigated by earthen dams is the strongest explanation for understanding the degree of variance captured by household endowment scores (Table 1).

(3) Previous leadership experience. It is important to note that differences in caste or wealth status need not necessarily prevent groups from working together in a society that shares values of democratic governance. For example, between 1995 and 2000, the water contractor (Bant Ram) was the Sarpanch (chief) of the Bharauli local government. He had developed experience successfully leading a disparate group of people drawn from the different caste groups. Although caste rules prevented groups from inter-marriage or sharing of public space, they were fully capable of collaborating based on common but secular interests.

\section{The Entrepreneur and Service Delivery Outcomes}

Our 2000 case study revealed that the strategic location of the entrepreneur's farm plots towards the end of the main distribution lines of the dam meant that he played an important coordination role in ensuring that farmers with plots located at the head of the distribution network did not monopolise water use. The absence of sons in his household meant that agriculture was the primary source of household income for the entrepreneur and heightened his interest in ensuring that water allocation rules were adhered to by resource users. ${ }^{2}$ Given his level of interest, we found that the entrepreneur in Bharauli purchased water distribution rights, arranged for routine maintenance of the dam and bore weather-induced risks as in 1997 when due to lower rainfall, farmers' compliance with user charges were adversely affected (Kurian \& Dietz, 2007).

The strong commitment of the entrepreneur to invest his resources (time and money) to ensure that water allocation rules were adhered to by resource users resulted in positive outcomes. By adapting Ostrom's use of the concept of 'water availability difference' (1994), we observed that the difference 
Table 2. Predictability of water supplied from earthen dams

\begin{tabular}{cccc}
\hline HRMS & $\begin{array}{c}\text { Level of water predictability } \\
\text { among head-end water users }\end{array}$ & $\begin{array}{c}\text { Level of water predictability } \\
\text { among tail-end water users }\end{array}$ & $\begin{array}{c}\text { Difference in water predictability } \\
\text { between head and tail-end water users }\end{array}$ \\
\hline Bharauli & 1.8 hours & 1.3 hours & 0.5 hours \\
Thadion & 1.7 hours & 0.1 hours & 1.6 hours \\
\hline
\end{tabular}

Source: Kurian \& Dietz, 2007.

in predictability of water supply between head and tail-end water users was lower in Bharauli when compared to Thadion (Table 2).

Reliable delivery of irrigation services also meant that the system was more efficient. Higher efficiency is reflected in the difference between average water requirements and water availability. Based on rule of thumb calculations of water requirements during the winter season rabi and mean land sizes, we arrived at the difference between water requirement and water availability. ${ }^{3}$ Greater reliability and efficiency of water use in Bharauli also explains the lower variance in costs incurred by consumers in purchase of water, which was 61.6 compared to 115.3 in Thadion. Greater reliability of water supply from the dam also created more contributions from group members (in labour or monetary terms) towards repair and maintenance of the earthen dam. Between 1995 and 2000, on average 3.7 days of labour were contributed towards repairs when compared to 2.3 in Thadion. Water users belonging to higher wealth classes made cash contributions of Rs 377 compared to Rs 156 in Thadion. Success with delivery of irrigation services from the dam in Bharauli also resulted in positive environmental outcomes. Forestry assessments that we undertook in the catchment of the earthen dams revealed regeneration of saplings ${ }^{4}$ was greater in Bharauli when compared to Thadion (Table 3).

Another environmental outcome evident from analysis of satellite imagery was that because of effective delivery of water services, land area under perennial agriculture increased by 60 acres in Bharauli (NRSA, 1999). Another 30 acres of land previously prone to riverbed erosion was reclaimed and cultivated with cash crops like radish, onions and chillies in the winter season. Within the constraints imposed by topography of the command area of the dam, the water entrepreneur played an important coordination role in balancing between the demands of competing water users for a share of water resources. Interests of large landholders with political influence and members of his extended family received priority in his plans for extending the area of the dam distribution network.

While environmental outcomes of contractor-based service provisions were generally encouraging we found that results were mixed when we examined distribution of benefits among resource users. This assertion is supported by the fact that crop intensity rates, agricultural incomes, productivity increases for wheat and acreage under irrigation from the earthen dam tended to favour high endowment category households when compared to poorly endowed ones. From a political ecology

Table 3. Forest regeneration in the catchment of Bharauli dam

\begin{tabular}{lcc}
\hline Parameter & Bharauli forest & $\begin{array}{c}\text { Control forest belonging to community with failed } \\
\text { collective action (Thadion) }\end{array}$ \\
\hline Slope (in degrees) & 11 & 15.1 \\
Plots with high intensity of & 11.1 & 46.6 \\
$\quad$ soil erosion (\%) & 11 & 8 \\
No. of saplings & 1.81 & 0.35 \\
Basal area of trees (metres) & 6.42 (significant at 5\% & 2.78 \\
Basal area of saplings & confidence level) & 1.54 \\
$\quad$ (centimetres) & 2.08 & 3.53 \\
Diversity of saplings & 7.72 & \\
Density of saplings & & \\
\hline
\end{tabular}

Source: Kurian \& Dietz, 2007. 
perspective, although acreage under irrigation was highest for high endowment category households, when we examined the proportion of land area irrigated as a percentage of land ownership we found that poorer households (low and medium endowment category) benefited more than wealthier (high endowment category) households. This difference can be explained by spatial variation in location of individual farm plots within the dam command area. We also found with a doubling of agricultural yields under irrigated conditions, the workload for women (a culturally and educationally marginalised group in the region) had risen more than that for men (Kurian \& Dietz, 2005).

\section{Measures of Group Heterogeneity/Homogeneity}

The influence of group heterogeneity/homogeneity on collective action is complicated because it is multi-dimensional and, mechanisms linking heterogeneity/ homogeneity and collective action are recursive and non-monotonic (Bardhan \& Dayton-Johnson, 2002). For these two reasons, we chose to embed our analysis of asset, income or caste heterogeneity/homogeneity within processes of social differentiation involving changing types of relationships between wealthier and poorer farmers in the context of commodity relations, local power structures and historically defined social exchange (Bebbington, 1999). Given this choice of approach, we identified measures of group heterogeneity/ homogeneity by constructing household endowment and household interest scores (Online Appendix). To construct household endowment scores we considered four variables: 1) total rain-fed land owned, 2) total irrigated land owned, 3) type of livestock owned, and 4) size of household. In constructing household endowment scores, we devised weights for each of the assets outlined above. The weights were based on food productivity assessments ${ }^{5}$ undertaken in Shiwalik villages (Kurian \& Dietz, 2007).

To construct household interest scores we made some assumptions. First, we assumed that the larger the area irrigated by a dam, the greater the interest in its use, conversely, the smaller the area the lower the interest. Second, the greater the reliability afforded by alternative sources of irrigation for damirrigated land, the smaller the farmers' interest would be in contributing towards dam repairs. Finally, the greater the area under irrigation outside the dam command area, the lower the interest in participating in collective action (purchasing water distribution rights during the annual auction or contribution towards maintenance). Interest scores of 1, 2, 4, 8 and 16 were decided based on household food productivity assessments. We noticed that access to irrigation could increase wheat production per acre by a factor of two. Likewise, irrigation could increase the number of people fed from one acre of land by a factor of two. In determining weights for: 1) area irrigated by the dam, 2) alternative sources of irrigation for dam-irrigated land, and 3) land area outside dam command, we allocated weights that differed by a factor of two (Kurian \& Dietz, 2004).

\section{Establishing Links between Behaviour Change and Condition of Natural Resources}

We undertook forestry vegetation studies to examine links between behaviour change in the form of stall feeding livestock and forest condition. Thirty-three plots were laid in forests under the management of Bharauli and Thadion HRMS. Within each 10-metre plot, smaller plots of 5 and 1 metre were laid. Within the 10-metre plot, local names of trees with girth exceeding $10 \mathrm{~cm}$ were enumerated. Within the 5-metre plot, saplings with girth in the range of 2.5 to $10 \mathrm{~cm}$ were enumerated. Within the 1-metre plot, the density and girth of all shrubs and saplings with girth less than $2.5 \mathrm{~cm}$ were enumerated. In addition qualitative information on soil erosion, livestock use, presence of epiphytes and slope characteristics were collected from each plot (IFRI, 1997).

\section{Co-Provision and Service Delivery: Role of Local Leadership}

In 2008 we returned to our study site to examine how collective action had evolved over an eight-year period since our initial study. We found that as a result of several years of failure to promote collective action, the dam in Thadion had silted up and resource users had moved towards private water provisioning from tube wells. On the other hand we found that collective action for dam management 
had continued in Bharauli. In the ensuing discussion we adopt a longitudinal approach to examine the institutional basis of co-provisioning, its role in delivering irrigation services and implications of 'successful collective action' for design of contractual arrangements that promote equity and environmental conservation.

\section{Community Cohesion and Irrigation Management}

The population of Bharauli village increased from 80 households in 2000 to 125 households in 2008 . The village remains heterogeneous in caste composition: gujjars, rajputs, tarkhans and harijans being major castes. Occupational specialisation among caste groups is retained and forms of social segregation are intact as is evident in residential location and use of public amenities like water points. Livestock composition has not changed significantly. Similarly, Haryana Forest Department (HFD) staffing arrangements remain the same: two guards are responsible for monitoring the use of forest areas and organising annual water auctions. One significant development since our previous visit is the construction of a new dam in 2001 with a command area of 40 hectares. However, a combination of factors like high silt movement from forest catchment areas and poor design led to the dam falling into disrepair within the first year. Given its potential to irrigate an additional 50 hectares, the HRMS decided to plumb distribution pipes from this new dam into the first dam we studied in $2000 .^{6}$ This meant that when water levels declined in the first dam, water from the new dam (located not too far away) was now available to ensure a reliable supply of water.

No new dam was constructed in Thadion although the dam there had fallen into disrepair due to siltation. In discussions with HFD, it became clear that officials considered another dam in Bharauli to be a safe investment given its prior record of natural resource management. It can be gleaned from minutes of meetings maintained by staff of the community watershed project that Bharauli was more adept at 'arriving at a clear delegation of tasks to ensure that auctions were organised, records of funds were maintained and periodic repairs of dams were undertaken' (Sarin, 1991, p. 5). Conversely it was noted in Thadion that 'HRMS meetings were seldom organised, records were poorly maintained and irrigation service fees were not collected because of conflicts among water users' (Sarin, 1991, p. 5). Despite obvious social and cultural diversity in Bharauli, the HRMS was more capable of appearing to public officials as a more cohesive community group. This success is attributable to the village water contractor who was able to balance the interests of a wide constituency when deciding on distribution of water from the earthen dam.

\section{Land Fragmentation Has Altered Thresholds of Collective Action}

The arrival of the new dam in 2001 meant that irrigation could now be provided to a larger group of households involving 40 extra ha of land in Bharauli and neighbouring hamlets of Kambala, Thadion and Rethi. This altered the distribution of household interests and endowments significantly. Thirtythree of 35 households we studied in 2000 witnessed an increase in acreage under irrigation with the arrival of the second dam. The increase in area under irrigation resulted in an increase in average size of irrigated land by 0.6 hectares since 2000. Further, between 2000 and 2008, sub-division of land holdings took place involving 10 water-using households. ${ }^{7}$ This could explain the increase in mean level of interest from 19.6 to 21.7. Both these factors contributed towards significant homogenisation of household endowments and interests. Table 4 makes it evident that there has been a reduction in

Table 4. Variance in distribution of household endowments and interests

\begin{tabular}{llr}
\hline Parameter & \multicolumn{1}{c}{2000} & \multicolumn{1}{c}{2008} \\
\hline Distribution of interest & $14.73($ mean= 19.6) & 4.37 (mean= 21.7) \\
Distribution of endowments & $69.1($ mean=9.3) & 49.03 (mean= 8.3) \\
\hline
\end{tabular}

Source: Kurian \& Dietz, 2007 and authors' revisited data 
variance in distribution of household endowments from 69.1 in 2000 to 49.03 in 2008 and a reduction in variance in distribution of household interest from 14.73 in 2000 to 4.37 in 2008. This ensured that a substantial number of the 15 additional households could receive irrigation water. Therefore, after allowing for land sub-division among the original water-user group and increased water availability because of the second dam, group size increased from 35 to 50 farming households.

\section{Withdrawal of the Original Entrepreneur from a Leadership Position}

Since the construction of the new dam in 2001, the original entrepreneur has been reluctant to purchase water distribution rights at water auctions. Instead, between 2002 and 2004, he participated as a member of the HRMS management committee. Between 2002 and 2003, an elected committee of the HRMS was responsible for organising service provisions. In 2004, two new entrepreneurs decided to purchase water distribution rights at auctions. However, they failed to ensure water distribution because of disagreements over hourly water allocation rules. As a result, farmers did not comply with the rule stipulating payment of an hourly water rate of Rs 10 (Table 5). Nevertheless, our analysis suggests that the entry of these two new entrepreneurs signifies democratisation of decision making with regard to the management of the dam in Bharauli. The reduction in the tariff for water besides reflecting a broad-based perception of reduced water scarcity could also suggest that the scope for arbitrary tariff setting by a profit-maximising entrepreneur could now be curbed by the presence of countervailing influences within the water-user group. The following trends evident since our initial visit support this contention:

- The threshold endowment level, which signifies households with potential to engage in service provision declined from 15.6 to 12.9 .

- The number of households with endowments higher than the threshold level had increased from four to eight.

- The number of households most certain to provide a collective good (higher resources matched with higher than mean level of interest) had risen from one to three.

- The variance in endowment distributions for households most certain to provide a collective good declined from 20.4 to 14.5 between 2000 and 2008 .

- The mean level of interest increased from 19.6 to 21.7 during the same period.

Table 5. Trends in mode of provision and water tariffs at Bharauli

\begin{tabular}{llll}
\hline Year & $\begin{array}{c}\text { Lease amount paid by entrepreneur to } \\
\text { HRMS at auction }\end{array}$ & $\begin{array}{c}\text { Hourly user } \\
\text { fee }\end{array}$ & \begin{tabular}{l} 
Entrepreneur success with cost - recovery \\
\hline $1997-1998$
\end{tabular} \\
& Rs. 20,000 & Rs 25 & $\begin{array}{l}\text { No profits due to poor payments arising } \\
\text { from poor rains }\end{array}$ \\
$1998-1999$ & Rs. 18,800 & Rs 25 & Rs 7,500 \\
$1999-2000$ & Rs. 18,600 & Rs 25 & Rs. 4,000 \\
$2000-2001$ & HRMS provisioning & Rs 10 & Not applicable \\
$2001-2002$ & HRMS provisioning & Rs 10 & Not applicable \\
$2002-2003$ & HRMS provisioning & Rs 10 & Not applicable \\
$2003-2004$ & HRMS provisioning & Rs 10 & Not applicable \\
$2004-2005$ & Rs. 14,000 & Rs 10 & Low payments resulting in no profit \\
$2005-2006$ & Rs. 14,500 & Rs 10 & Low payments resulting in no profit \\
$2006-2007$ & HRMS provisioning & Rs 10 & Not applicable \\
\hline
\end{tabular}

Source: Kurian \& Dietz, 2007 and revisited data 


\section{Conditions of Successful Leadership}

The inability of the two new entrepreneurs to ensure collective action despite a lowering of the water tariff lead us to examine some of the conditions that supported the success of the original entrepreneur. Our analysis points to three conditions that may explain his success as a leader.

(1) Moral basis of power and authority. Caste status when examined in the context of wealth differentials provides an accurate description of power sources. Wealth ranking discussions with a cross-section of water users and village residents revealed that irrigated land was considered a source of power. Interestingly, when we considered other factors such as land size or ownership of tractors we were able to identify a different sub-set of individuals within the group. But when we ranked households based on the composite endowment index that we developed, we were able to identify the water contractor as a powerful individual. He owned the largest acreage of irrigated land, owned a tractor and possessed a small family, which implied fewer mouths to feed and potential to retain a large grain surplus that could be sold in local markets. Land sub-division at the time of marriage of male children has the potential to reduce levels of household wealth. However, the absence of male children in his family posed no secular threat to household wealth. Our focused group discussions revealed the contractor to be a benevolent patron despite his ability to control access to credit, land and labour in the village. For instance, the water contractor has traditionally been a source of credit at times when crops failed due to pests or drought. He also is known to provide loans for weddings, thereby cementing his position in the moral economy of the village. Discussions revealed that in the past when loans were not repaid on time, the ownership of land that was pledged as collateral was transferred to the water contractor after allowing for a sufficient grace period. During harvest periods when family labour is insufficient to perform harvesting and threshing tasks, labour from landless households is hired. Labourers are not always paid in cash. Instead, by being viewed as an extension of the patron's family, labourers and their families are compensated in the form of food or credit to purchase household items at the village store. In all cases, households remain obliged to patrons for help rendered as when in 1984 the water contractor advanced an interest free loan to repair the homes of landless families whose homes had been washed away in a flood.

(2) Political factions. In 1995 Bant Ram (the water contractor) did not own the largest area of land in the village. That distinction belonged to another powerful person in the village, Jagir Singh, who represents a powerful political faction. Political factions in the village are typically represented by members of the extended family of the patron (brothers, cousins) and clients (landless labourers). There are complex social norms that dictate behaviour within factions. For example, an unwritten rule during a water auction is that members of a particular faction will not compete once one of their members has decided to place a bid. Prior to arrival of irrigation in the village, Jagir Singh dominated politics in the village. He served as liaison with local government. For instance, documents show how Jagir Singh travelled to a nearby village to meet the District Commissioner to petition him to supply distribution pipes for the newly built dam in Bharauli. A sum of Rs 3,38,926 was eventually disbursed in 1995-1996 to facilitate repair of the dam (HFD, 2000). However, the laying of distribution pipes was not a simple affair. There was intense jostling among farmers to get the pipes to pass through their fields. While allowing for constraints imposed by topography, when the pipes were finally laid, the water contractor had the largest acreage under irrigation in the village. Jagir Singh, with the larger family and more mouths to feed, was no longer in a position to exercise his power as he once used to do. Power had shifted gradually to a new political faction led by the water contractor. ${ }^{8}$ Incidentally, the two entrepreneurs who attempted a leadership role but failed in 2004 did not belong to either of two political factions in the village.

(3) Calculus of profit. Our revisit in 2008 reveals that desilting of the dam pondage area is a pressing requirement, but the important question that arises in this context is what type of contract form (HRMS vs. entrepreneur) is better placed to bear the political risks associated with required tariff 
increases to facilitate adaptive environmental management. The combined effect of increasing group size (facilitated by land fragmentation) and lower tariffs (shaped by emergence of countervailing forces within HRMS) has potential to alter the 'threshold of co-provision'. The threshold of co-provision is a function of: 1) marginal revenue derived from extending the irrigation network to accommodate new resource users who are paying a reduced tariff, and 2) availability of public subsidies that would enable the entrepreneur to retain the possibility of making a profit while charging poor consumers a lower tariff and undertaking desilting of the dam pondage area. The absence of fiscal support from government could explain the withdrawal of the water contractor from a leadership position in irrigation management.

\section{Implications for Theory}

Public choice theory offers useful perspectives and conceptual tools for analysis that focuses on the start-up phase of collective action. Besides emphasising rational action and the importance of information in individual decision making, public choice theory has offered a categorisation of common pool goods as non-excludable and 'rivalrous' in consumption. Such a categorisation can help delineate transaction costs related to: 1) transforming resource user preferences and their willingness to pay into articulated demands for packages of publicly provided goods and services, 2) arranging to finance and produce these packages, 3) monitoring performance, 4) regulating consumer use patterns, and 5) enforcing compliance with resource mobilisation techniques (Schroeder \& Wynne, 1993). The notion that the value of a given level of collective good could decline proportionately with the number of users who share in its use can be useful in structuring incentives for participation in managing common pool resources (Heckathorn, 1993; Oliver and Marwell, 1993). In this connection Olson's formulation of 'selective incentives' led him to argue that smaller groups may be more amenable to exercise such incentives when compared to large groups (Olson, 1965, p. 62).

Poteete and Ostrom (2008) highlight the role that different production technologies can have in influencing distribution of interest: particularly when the technology used by one group within the same community has negative impacts on the use of a resource by others (Baland \& Platteau, 1999; Poteete \& Ostrom, 2004, p. 443). ${ }^{9}$ Oliver and Marwell used the concept of 'thresholds to action' to argue that two conditions must be met for heterogeneity to be beneficial or harmful for collective action (1993, p. 21). The first is the mean level of distribution. If the mean distribution level is too low, so that individuals with the mean value are unwilling to participate, greater heterogeneity will force a higher proportion of people into the upper percentage of willing participants, and thereby promote collective action. ${ }^{10}$ In contrast, if the mean is already high enough to favour collective action, greater heterogeneity would put a greater proportion of cases into the lower end of the distribution where people are unwilling to participate, and thus would not be helpful to collective action. The second condition relates to 'conjunction of probabilities'. Simply, when groups are heterogeneous, there is a risk that people with enough resources to provide the collective good will not be interested enough in the good to contribute. In this connection, it has been pointed out that the presence of private alternatives can dissuade wealthy individuals from investing time or money to meet start-up costs of collective action (Bardhan \& Dayton-Johnson, 2002).

The limitations of public choice theory become apparent, however, when our concern is not limited to the start-up phase of collective action but extends to include an understanding of the conditions that would sustain rule making, enforcement and modification over time. For instance, our revisit highlights two conundrums: 1) if the decision to undertake a leadership role is based purely on a rational cost-benefit calculation relying on available information, then why did the new entrepreneurs decide to purchase the right to allocate water when the tariff for water had been reduced the year before?; 2) from a methodological point of view how is it possible that an approach based on the use of statistical means could not explain the emergence of the new entrepreneurs to support provision of a collective good although they retained a 'conjunction of probability' - an interest in the dam backed by the financial resources required to operate the system? From a theoretical standpoint, we may conclude 
that while an increase in group size (resource users) need not be a constraint, the inclusion of new members with whom entrepreneurs do not have a past history of working together can prove detrimental to cooperation. A study of rangeland management in Kenya, for example, showed that inducting new members from dispersed hamlets involving ever-widening ethnic and cultural differences reduced the possibility of cooperation (Galaty, 1988).

Our analysis leads us to argue that effective co-provision is an outcome of strategic manipulation of local power structures (potentially involving competing factions) and exploitation of social ties with representatives of the local state to facilitate the delivery of public services. In most cases co-provision is made possible by leaders who operate in milieu of caste and gender-based hierarchical social relations, exercise of discretion by public officials, uncertainty in factor and product markets and risks posed by variability in climatic, soil and groundwater conditions. Our methodology, by focusing on developing a composite index of interest and endowments based on assessments of household food security, constitutes an improvement over single metric measures (land or income) of wealth distribution. Such an approach is better placed to understand institutional processes by which differential access to assets (such as irrigated land, credit or labour) at the level of individual households are translated into power (White, 1989). Power is understood here as the extent to which one could control the action of others; from recourse to use of cultural symbols like gift giving (Thapar, 1994). Power can also be exercised through patronage relations between landed and landless households that are embedded in labour tying and informal credit arrangements that serve to insure groups against market and climate-based risks ${ }^{11}$ (Kozel \& Parker, 2003; Scott, 1976). Our approach offers us a nuanced understanding of differentiation as a dynamic process involving the sharpening of differences within a population that does not necessarily constitute increasing inequalities in income or access to land (White, 1989).

The attributes of leaders reflected in their ability to raise resources, organise labour and implement repairs of public infrastructure can be supported by higher order inter-governmental financing processes that ensure their access to subsidies and performance-based grants (World Bank, 2004). In this connection, a re-articulation of the state's role is imperative to ensure that its role is not limited to 'a minimal recognition of rights of groups to organize' (Ostrom, 1990, p. 90) but to ensure greater accountability in public sector decision-making. Policy science can help by shifting the focus from infrastructure spending by identifying budgetary strategies and instruments that emphasise improved service delivery outcomes as they relate to reliability, adequacy, affordability and quality (World Bank, 2009). Unaccountable fiscal behaviour poses particular challenges to environmental management because of the non-linearity inherent in processes that link policy interventions and environmental outcomes at different scales (Scoones, 1999). Our study also emphasises the attributes of political factions and their potential to influence the success of leaders in achieving cooperative outcomes. Studies show where there are several households much wealthier than the rest and approximately equal to each other factional competition may intensify (Wade, 1988). Vedeld's (2000) study of Fulani villages led him to conclude that homogeneity of interests among elite groups enhanced the possibility of collective action. Prospects of mutual aid and power sharing among factions are likely to flounder given a history of past conflict involving wide ethnic differences (Bandopadhyay \& Eschen, 1988).V.

\section{Conclusions}

Scholars focussed on economic performance have emphasised the importance of a stable polity with complementary norms that can provide the flexibility required to adjust to evolving technological and demographic changes as well as shocks to the system (North, 1995). With respect to the developing world however, there is an acknowledgement that policies focused on enhancing public sector efficiency perceived to be inequitable will engender political reactions. It has been argued in this connection that one pathway to beneficial institutional change in the short term could be to remove a critical political obstacle: asymmetries in political bargaining power (Bardhan, 2005). It is precisely this short-term perspective on institutional change that has guided policy interventions focused on 
management of CPRs. A key assumption that guided this phase was targeting homogeneous groups on the belief that opportunities for political bargaining over benefit distribution will be promoted because of broad-based equality in income and land ownership and absence of deep cultural divisions within such groups.

This article, by reporting on the findings of a revisit to a site of successful collective action, emphasises the benefits of adopting a longer-term view that would accommodate a nuanced understanding of the state's role in supporting wealth accumulation strategies, land fragmentation and leadership change within groups of resource users. Such a perspective can yield a number of insights on the conditions that make rule making, enforcement and modification possible. Rational choice scholars offer us valuable perspectives on the structure of costs and benefits of providing a collective good. However, longitudinal analysis that is rooted in a moral economy of wealth-based inequality can further improve our understanding of how to strengthen feedback loops between policy, structural change within communities and contract forms that facilitate delivery of services while accommodating for changes in the natural environment (Poteete \& Ostrom, 2008). Feedback loops are especially important in supporting effective co-provision because of the imperative to 'strategically manipulate a network of social relations and discipline the discretion of other agencies' (Long \& Ploeg, 1992, p. 17).

Our study shows that the absence of historical narrative in analysis of collective action by rational action scholars can lead us to over-emphasise the risks of elite capture (Mosse, 1997). However, in as much as the wealthy are guided by the calculus of profit their actions can be motivated by a moral basis. Previous leadership experience and familiarity of working together to achieve secular goals can bridge wide differences in culture and ethnicity. As a result increasing group size need not a priori pose a threat to collective action. A more portent threat to leadership in pre-industrial societies, however, lies in the perception that some of its members accumulate wealth while others are in need (Fafchamps, 1992). Therefore, one of the positive benefits of external intervention can be to expand opportunities for the poor and non-poor to cooperate since coalitions made up exclusively of the poor are likely to remain powerless in dealing with the challenges posed by poor standards of service delivery (World Bank, 2004).

Irrigation is systematically linked to major features of social organisation, closely affected by differential power and embedded in the local-national linkages of states (Hunt \& Hunt, 1976). Hierarchy arising from inequality in wealth distribution is a key feature of pre-industrial societies. CPR research on the effect of heterogeneity on collective action led us to inquire if an equalisation of wealth differentials will remove constraints to the development of trust and shared norms. Our revisit study leads us to conclude that social hierarchies rooted in a moral economy may be necessary especially because not all people within a community can be relied upon to live by their internalised ethical rules and contribute their fair share (Fukuyama, 1995). From a methodological point of view, how one integrates conceptualisation of forms of heterogeneity with recognition of their axis of influence dependent on the attributes of field-level situations is critical for analysis of collective action (Poteete, Janssen, \& Ostrom, 2010). Longitudinal studies, like the one discussed in this article that analyse historical processes extend existing theories by providing insights on levers of social control that are likely to translate effects of social hierarchy into tangible service delivery outcomes.

\section{Acknowledgements}

This article is a culmination of 15 years of research focused on understanding the institutional basis of cooperation in natural resources management. We pay a special tribute to Elinor Ostrom who played an instrumental role in shaping the research questions posed by this project. The study design benefited from extensive peer review by colleagues at International Forestry Resources and Institutions (IFRI) research programme at the Workshop in Political Theory and Policy Analysis, Indiana University, Bloomington, International Institute of Social Studies, Erasmus University, The Hague, Netherlands, Asian Development Bank, Manila, International Water Management Institute (CGIAR), Colombo, Bangkok and Addis Ababa and Tata Energy Research Institute, New Delhi. A 
number of individuals at numerous organisations worldwide collaborated and supported this project notably: Ashwani Saith, Kenichi Yokoyama, S. Sreekesh, K.S. Murali, Frank Rijsberman, Lubina Qureishy, Charlie Schweik, Minoti Kaul, O. N. Kaul, Venkata Ramana, S. K. Dhar, Yu Kojima and Mom and Dad for life's bigger questions on structure, hierarchy and change.

\section{Notes}

1. Each family or gotra is allocated water from the $k u h l$ or seasonal water channel by a 12-hour rotation. One water user has responsibility for monitoring the rotation. For his services, he receives six hours of water annually from the kuhl in excess of his designated share of 20 minutes of water per distribution cycle. The size of their land holding determines the number of water-hours a household receives (Kurian \& Dietz, 2004, p. 39).

2. Cultural factors among communities like the Gujjars prevent unmarried women from engaging in non-farm labour markets.

3. During a period of normal rainfall, three rounds of watering are required for a wheat crop. Four hours are required to water one acre of wheat crop from the dam. Mean land size among water users in Bharauli was 4.7 acres. Therefore, mean percapita water requirement for water users is 18.8 hours (4.7 times 4). In 1999-2000, 555 hours of water was supplied in Bharauli at a mean per capita rate of 16.1 hours. In Thadion, mean land size was 5.8 acres. Therefore, mean per capita water requirement for water users was 23.2 hours (5.8 times 4). In 1999-2000, 479 hours of water was supplied in Thadion at a mean per capita rate of 32 hours.

4. Sapling regeneration is a good indicator of the relationship between behaviour change (open grazing of cattle) and forest condition. Saplings regenerate in a relatively short period (four to six years) when compared to trees, which take a much longer time to reflect changes in behaviour (Becker \& Leon, 2000: IFRI, 1997).

5. For an interesting discussion on the usefulness of calorific terms of trade to understand dimensions of household livelihood strategies, see Dietz, Nunow, Roba and Zaal (2001).

6. Earthen dams continue to be the main technology supported by public investment in the region as is evident from sanctions for construction of two new dams in a neighbouring village.

7. Sub-division occurred when male members received their share of property at marriage. In the Haryana context when girls are married into another village, her husband benefits with sub-division land in his village. The girl leaves her village with movable items such as gifts, household items and money. It is unlikely she inherits land except in cases where she returns to her parents' house due to her husband's death or divorce (Agrawal, 1994).

8. For an interesting analysis of the role of factions in rural development, see Bandhopadyay and Eschen (1988) and Vedeld (2000).

9. A study by Balasubramanian and Selvaraj (2003) in South India points out that an increasing number of private tube wells in a watershed had a negative effect on collective action for maintenance of public tanks.

10. In this context, it has been argued that chances of elite capture may arise since a group of highly interested and resourceful individuals may cooperate to derive benefits by excluding resource poor individuals from participating in management of the common pool resource (Platteau \& Gaspart, 2003).

11. For example, studies in rural India have shown how labour tying ensures that contributions by asset less households towards their patrons' collective endeavours (for example operating and maintaining an irrigation system) are compensated not in monetary terms but in terms of access to free food, especially during times of natural disaster (Bardhan, 1984).

\section{References}

Agrawal, B. (1994). A field of one's own-gender and land rights in South Asia. South Asia Studies 54. London: Cambridge University Press.

Agrawal, B. (1997). Gender, environment and poverty inter-links: Regional variations and temporal shifts in rural India, 1971-1991. World Development, 25, 23-52.

Arya, S. L., \& Samra, J. S. (1995). Socio-economic implications and participatory appraisal of watershed management project at Bunga (Bulletin No. T-27/C-6). Central Soil and Water Conservation Research and Training Centre, Chandigarh.

Baland, J. M., \& Platteau, J. P. (1999). The ambiguous impact of inequality on local resource management. World Development, 27, 773-788.

Balasubramanian, R., \& Selvaraj, K. N. (2003). Poverty, private property and common pool resource management: The case of irrigation tanks in south India (SANDEE Working Paper No. 2-03). Katmandhu, Nepal.

Bandhopadyay S., \& Eschen, D. (1988). Village failure to cooperate: Some evidence from West Bengal, India. In D. Attwood \& B. Baviskar (Eds), Who shares? Cooperatives and rural development (pp. 112-145). New Delhi: Oxford University Press.

Bardhan, P. (1984). Land, labour and rural poverty: Essays in development economics. New York: Columbia University Press.

Bardhan P. (2005). Scarcity, conflicts and cooperation - essays in the political and institutional economics of development. Cambridge, MA: MIT Press.

Bardhan, P., \& Dayton-Johnson, J. (2002). Unequal irrigators: Heterogeneity and commons management in large-scale multivariate research. In National Research Council (Ed.), The drama of the commons (pp. 51-67). Washington, DC: National Academy Press. 
Bebbington, A. (1999). Capitals and capabilities: A framework for analyzing peasant viability, rural livelihoods and poverty. World Development, 27, 2021-2044.

Beck, T., \& Nesmith, C. (2001). Building on poor people's capacity: The case of common property resources in India and West Africa. World Development, 29, 119-133.

Becker, D., \& Leon, R. (2000). Indigenous forest management in the Bolivian Amazon: Lessons from the Yuracare people. In C. C. Gibson, M. A. McKean, \& E. Ostrom (Eds.), People and forests: Communities, institutions and governance (pp. 89-105). Cambridge, MA: MIT Press.

Bhalla, S. (1999). Liberalization, rural labour markets and the mobilization of farm workers: The Haryana story in an all India context. Journal of Peasant Studies, 26, 62-88. January/April.

Brookfield H., \& Blaikie P. (1987). Land degradation and society. London: Methuen.

Byron, N., \& Arnold, M. (1999). What futures for the people of tropical forests? World Development, $27,789-805$.

Dasgupta, A., \& Beard, V. (2007). Community driven development, collective action and elite capture in Indonesia. Development and Change, 38, 229-249.

Datta, S. \& Varalakshmi, V. (1999). Decentralization: An effective method of financial management at the grassroots. Sustainable Development, 7, 113-120.

Dhar, S. K. (1994). Rehabilitation of degraded tropical forest watersheds with people's participation. Ambio, $23,72-84$.

Dietz, T., Nunow, A., Roba, A., \& Zaal, F. (2001). Pastoral commercialization: On caloric terms of trade and related issues. In M. Salih, T. Dietz, \& A. Ahmed (Eds.), African pastoralism: Conflicts, institutions and government (pp. 132-143). Utrecht: Pluto Press.

Easter, K., \& Palanisami, K. (1986, August). Tank irrigation in India and Thailand: An examination of common property management (Staff paper). University of Minnesota, Department of Agriculture and Applied Economics.

Fafchamps, M. (1992). Solidarity networks in pre-industrial societies: Rational peasants with a moral economy. Economic Development and Cultural Change, 41, 147-174.

Fukuyama, F. (1995). Trust: The social virtues and the creation of prosperity. New York: Penguin.

Galaty, S. (1988). Rangeland management projects in Kenya. In D. Attwood \& B. Baviskar (Eds.), Who shares? Cooperatives and rural development (pp. 112-145). New Delhi: Oxford University Press.

Grewal, S., Samra, J., Mittal, S., \& Agnihotri, Y. (1995). Sukhomajiri concept of integrated watershed management (Bulletin No. T-26/C-5). Central Soil and Water Conservation Research and Training Institute, Chandigarh.

Heckathorn, D. (1993). Collective action and group heterogeneity: Voluntary provision versus selective incentives. American Sociological Review, 58, 329-350.

HFD (2000). Repairs of dams undertaken by the Shiwalik Development Board. Pinjore: Morni-Pinjore Forest Division.

Hunt, C., \& Hunt, W. (1976). Canal irrigation and local level social irrigation. Current Anthropology, 17, 389-398.

IFRI. (1997). International forestry research and institutions protocols, version 7. Workshop in political theory and policy analysis, Bloomington, Indiana.

Johnson, C. (2004). Uncommon ground: The poverty of history in common property discourse. Development and Change, 35, 407-433.

Jones, E. (2004). Wealth based trust and the development of collective action. World Development, 32, 691-711.

Kozel, V., \& Parker, B. (2003, January 25). A profile and diagnostic of poverty in Uttar Pradesh, Economic and Political Weekly, 385-403.

Kurian, M. (1998). Issues in newsprint sector reform. Public Enterprise, 16, 127-138. International Centre for Public Enterprise, Slovenia.

Kurian, M., \& Dietz, T. (2004). Irrigation and collective action: A study in method with reference to the Shiwalik Hills Haryana. Natural Resources Forum, 28, 34-49.

Kurian, M., \& Dietz, T. (2005). How pro-poor are participatory watershed management projects? An Indian case study (Research report No. 92). Colombo: International Water Management Institute.

Kurian, M. \& Dietz, T. (2007). Hydro-logic: Poverty, heterogeneity and cooperation on the commons. New Delhi: Macmillan. Lam, W. (2001). Coping with change: A study of local irrigation institutions in Taiwan. World Development, 29, 1569-1592.

Long, N., \& J. Ploeg. (1992). Heterogeneity, actor and structure: Towards a reconstitution of the concept of structure. In N. Long and A. Long (Eds.), Battlefields of knowledge - the interlocking of theory and practice in social research and development (pp. 12-24) London: Routledge.

McKean, M. (2000). Common property: What is it? What is it good for? And what makes it work? In C. Gibson, M. McKean, \& E. Ostrom (Eds.), People and forests - communities, institutions and governance (pp. 21-39). Cambridge, MA: MIT Press.

Mosse, D. (1997). The symbolic making of a common property resource: History, ecology and landscape in a tank irrigated landscape in South India. Development and Change, 28, 467-504.

Myers N. (1997). The world's forests: Problems and potentials. Environmental Conservation, 23, 156-168.

North, D. (1995). The new institutional economics and Third World development. In J. Harriss, J. Hunter, \& C. Lewis (Eds.), The new institutional economics and Third World development (pp. 17-26). London and New York: Routledge.

NRSA (1999, April 6). IRS-1B LISS-II geo coded satellite imagery. National Remote Sensing Agency, Hyderabad.

Oliver, P., \& Marwell, G. (1993). The critical mass in collective action: A micro-social theory. New York: Cambridge University Press.

Olson, M. (1965). The logic of collective action: Public goods and the theory of groups. Cambridge: Cambridge University Press. 
Ostrom, E. (1990). Governing the commons: The evolution of institutions for collective action. Cambridge: Cambridge University Press.

Ostrom, E. (1994). Constituting social capital and collective action. Journal of Theoretical Politics, 6, 527-562.

Ostrom, E. (1996). Crossing the great divide: Coproduction, synergy and development. World Development, $24,1073-1087$.

Peluso, N. (1992). Rich people, poor forests: Resource control and resistance in Java. Los Angeles: University of California Press.

Platteau, J. P., \& Gaspart, F. (2003). The risk of resource misappropriation in community driven development. World Development, 31, 1687-1703.

Poteete, A., \& Ostrom, E. (2004). Heterogeneity, group size and collective action: The role of institutions in forest management. Development and Change, 35, 435-461.

Poteete, A., \& Ostrom, E. (2008). Fifteen years of empirical research on collective action in natural resource management: Struggling to build large N-databases based on qualitative research. World Development, 36, 176-195.

Poteete, A., Janssen, M., \& Ostrom, E. (2010). Working together - collective action, the commons and multiple methods in practice. Princeton, NJ: Princeton University Press.

Rijsberman, F. (2004). Sanitation and excess to clean water. In B. Lomborg (Ed.), Global crises, global solutions (pp. 41-59). New York: Cambridge University Press.

Ruttan, L. (2008). Economic heterogeneity and the commons: Effects on collective action and collective goods provisioning. World Development, 36, 969-985.

Sarin, M. (1991). Methodology testing exercise in Trilokpur village, Raipur Rani range. Personal communication.

Schroeder, L., \& Wynne, S. (1993). Institutional incentives and sustainable development: Institutional policies in perspective. Boulder, CO: Westview Press.

Scoones, I. (1999). New ecology and the social sciences: What prospects for a fruitful engagement? Annual Review of Anthropology, 28, 479-509.

Scott, J. C. (1976). The moral economy of the peasant-rebellion and subsistence in south-east Asia. New Haven, CT: Yale University Press.

Shanmugarathnam, N. (1996). Nationalization, privatization and the dilemmas of common property resource management in Western Rajasthan. Journal of Development Studies, 33, 163-187.

Tang, S. (1992). Institutions and collective action - self irrigation in irrigation. San Francisco, CA: Institute of Contemporary Studies Press.

Thapar, R. (1994). Cultural transaction in early India. Oxford: Oxford University Press.

Varalakshmi, V. (1993). Economics and goat and buffalo rearing - a case study from Haryana (Joint Forest Management Series, No. 4). Tata Energy Research Institute, New Delhi.

Vedeld, T. (2000). Village politics: Heterogeneity, leadership and collective action. Journal of Development Studies, 36, 105-134.

Wade, R. (1988). Village republics: Economic conditions of collective action in south India. New York: Cambridge University Press.

White, B. (1989). Problems in the empirical analysis of agrarian differentiation. In G. Hart, A. Turton, \& B. White (Eds.), Agrarian transformations: Local processes and the state in South East Asia (pp. 45-61). Los Angeles: California University Press.

Woolcock, M., \& Narayan, D. (2001). Social capital: Implications for development theory, research and policy. The World Bank Research Observer, 15, 225-249.

World Bank. (2004). Making services work for the poor. World Development Report. Washington, DC.

World Bank. (2009). Output based aid: A compilation of lessons learned and best practice guidance. Washington, DC: GPOBA and IDA-IFC Secretariat. 